UDK: 82-1(510):82-1(44)

COPYRIGHT (O): GIUSI TAMBURELLO

\title{
Baudelaire's Influence on Duo Duo's Poetry through Chen Jingrong, a Chinese Woman Poet Translating from French
}

\author{
Giusi TAMBURELLO*
}

\begin{abstract}
As a woman poet, Chen Jingrong's productions encompassed the whole $20^{\text {th }}$ century: of particular interest are her poetry translations from the French language. Thanks to her translation work, valuable understanding of Charles Baudelaire's poetry was made available in China, which influenced the Chinese contemporary poet, Duo Duo, when he first started writing poetry during his youth. This paper tries to depict the importance of this contribution of Chen Jingrong and its effect on the process of renovation of the contemporary poetic scene in China.
\end{abstract}

Keywords: Chen Jingrong, Baudelaire, Duo Duo, contemporary Chinese poetry, translation

\section{Izvleček}

Opus kitajske pesnice Chen Jingrong zaobjema celotno 20. stoletje. Posebej zanimivi so njeni prevodi francoske poezije. Zahvaljujoč njenemu prevajalskemu delu je Kitajska spoznala poezijo Charlesa Baudelaira, ki je močno vplival na zgodnje mladostno ustvarjanje sodobnega pesnika Duo Duoja. Pričujoči članek poskuša prikazati pomen tega Chen Jingronginega doprinosa in njegov vpliv na proces prenove sodobne kitajske poezije.

Ključne besede: Chen Jingrong, Baudelaire, Duo Duo, sodobna kitajska poezija, prevodi

\footnotetext{
* Giusi Tamburello, PhD, Senior Lecturer, Dipartimento di Scienze Filologiche e Linguistiche, Facoltà di Lettere e Filosofia, Università degli Studi di Palermo, Italy. E-mail address: giuseppa.tamburello@unipa.it My special thanks to Sarah Scott and Brenda Beatty Epifani for their revising my English version.
} 


\section{Introduction}

Charles Baudelaire's poetry has been known in China since the beginning of the last century. The absorption of aspects of Western cultures during the period of the May $4^{\text {th }}$ Movement of 1919 included the first approach to this French poet. He was mentioned for the first time in 1919 by Zhou Zuoren in the preface to his poem Xiao he 小河 (Small River), which appeared in Xin qingnian 新青年 (New Youth), where he wrote that it "was slightly similar to the prose poetry by Baudelaire" (Tan Guilin 2004, 1-2, 1).

While Zhou Zuoren simply recalls Baudelaire in his preface, in the years following, as Tan Guilin (2004) very well describes in his History of Modern Chinese Literature, other intellectuals focused on the Frenchman's poetry, among them Xu Zhimo 徐志摩. At that time, there were published translations of Baudelaire's poems, and comments on his poetry took into consideration specific aspects of his poetics.

Nine of Baudelaire's poems were translated by Chen Jingrong 陈敬容 from French into Chinese and they were published in July of 1957 in the magazine Yiwen 译文 (Translations). ${ }^{1}$

These poems made a deep impression on Duo Duo 多多 ${ }^{2}$ years later when he, as a young poet, read them. Duo Duo's innovative style of poetry makes use of very strong images, which I believe, may, to a certain extent, be associated with the influence of Baudelaire's poetry on him through the translations by Chen Jingrong.

The strong images that appear in Duo Duo's poems are strikingly different from the general search for harmony to be found in Chinese poetry. They seem to me a characteristic of Duo Duo's poetry. This characteristic that defines a kind of "deviation" from what could be expected by the reader is the "starting point" of my analysis following the theoretical approach described by Leo Spitzer. ${ }^{3}$ I shall proceed through a close comparative reading of Baudelaire, Duo Duo and Cheng Jingrong in order to underline the elements that, in my opinion, bind the three

\footnotetext{
${ }^{1}$ The nine poems are collected under the title: 波德莱尔. 恶之花 Bodelai'er. E zhi hua (Boudelaire. The Flowers of Evil) (Chen Jingrong 1957, 132-43).

${ }^{2}$ Born in 1951 in Beijing, Duo Duo is one of the poets who have most deeply innovated contemporary Chinese poetry.

${ }^{3}$ Leo Spitzer (1887-1960) has described his stylistic approach to literary criticism in his works which I have read in Italian in the volume Critica stilistica e semantica storica, 1966.
} 
poets from the point of view of poetic image. As their literary production is quite broad, I shall have to restrict my analysis to some specific poems.

In particular, I shall take into consideration the poem Zaihui (Goodbye) written by Duo Duo in 1972. The way the elements of time and space are developed in the poem, the poet's choice of words in his images, recall Le crepuscule du soir (Dusk) by Baudelaire, one of the nine poems by the French poet translated by Chen Jingrong.

The close reading of the poems, as I shall try to demonstrate, suggests a deep impact by Chen's translations on the poetic choices made by Duo Duo.

\section{A Few Biographical Notes on Chen Jingrong}

When Chen Jingrong's translations of Baudelaire's poems were published, one hundred years had passed since their first publication in France in Les fleurs $d u$ mal (The Flowers of Evil). By that time, Chen Jingrong, whose biography shows a quite complicated life ${ }^{4}$, was 40 years old and the curator of Yiwen (Translations). She was a fighter all her life. Before she was even 18 , she attempted twice to run away from home to Beijing, a city which attracted her very much, so she could follow her teacher of English, Cao Baohua 草宝华, the great translator of MarxistLeninist works. She eventually succeeded during the second attempt. In Beijing, she could not attend the university regularly because she did not have the necessary financial means. Whenever possible, she attended lessons at the Universities of Peking and Qinghua. She earned some money by copying the manuscripts of translations made by Cao. She continued to study English by herself, and also took French lessons with the French widow of a teacher at Peking University. During that time, Chen became acquainted with the lively intellectual scene of which Cao himself was a part, and she met He Qifang 何其芳, Bian Zhilin 市之琳, and Ba Jin 巴金. In times of trouble, they were there to help her. The hectic political situation of China in those years of turmoil would not have made things any easier for Chen Jingrong. She frequently suffered from financial difficulties, at times living with her two daughters in temple ruins. Her private life was characterized by unlucky relationships. In spite of all these vicissitudes, her

\footnotetext{
${ }^{4}$ My research on Chen Jingrong includes a few papers published in recent years. A description of her biography which I refer to here can be found in the work L'acqua nei versi di Chen Jingrong (Tamburello 2009, 87-102).
} 
poetic production was quite remarkable. She wrote, in fact, more than three hundred poems that were collected in various volumes, and also published volumes of prose, translations and essays.

\section{The Atmosphere of the Time around Baudelaire's Poems}

The publication of Les fleurs $d u$ mal on June $25^{\text {th }} 1857$, was followed just two months later by problems when the poems were considered to be an offence to public decency. This fact, perhaps, gives a suggestion of their novelty at the time.

A few days after their publication, in Le Figaro, Gustave Bourdin wrote "Ce livre est un hôpital ouvert à toutes le démences de l'esprit [...] Rien ne peut justifier un homme de trente ans d'avoir donné la publicité du livre à de pareilles monstruosités" (Baudelaire 1973, 317). French society of the mid-19 $9^{\text {th }}$ century was not yet ready for the very peculiar approach to reality shown in Baudelaire's poems. Imagination is the basic element of Baudelaire poetics. When writing to Toussenel, at the beginning of 1856 , he stated: "The poet is supremely intelligent, intelligence par excellence, because he acts through the imagination that is the most scientific of the faculties because it is the only one that includes the universal analogy."6 (Rella 1990, 52).

Imagination is, therefore, what enables the poet to observe and catch reality in all aspects, without limitations. The poet can dig into the uncertainties of reality, its mistakes and dangers and still try to understand. A new kind of beauty arises, a beauty based on antinomy as the title itself of the collection, Les fleurs du mal, already suggests. (Rella 1990, 53)

Through the verses of Baudelaire, modernity somehow assaults the reader who is not yet ready to recognize it. In his dedication to Arsène Houssaye in Le Spleen de Paris (The Spleen of Paris), Baudelaire writes:

In this era of ambition, who among us has not dreamed of a poetic prose, musical without rhyme and without a steady pace, and flexible enough to adapt to broken lyrical movements of the soul, to the fluctuations in the fantasy, the jolts of consciousness? It is especially from the attendance of

\footnotetext{
5 "This book is a hospital open to all the dementias of mind [...] Nothing can justify a man of thirty years of giving publicity to such monstrosities book." In this paper, English translations from the original language are mine.

${ }^{6}$ This translation from Italian is mine.
} 
the huge cities and from the innumerable crossing of their relationships that this haunting ideal comes. You yourself, my dear friend, haven't you tried to translate into a song the shrill cry of the glassmaker and express into a lyrical prose all bleak suggestion that this call sends up to the attic through the thickest mists of the road? (Rella 1990, 53)

The observation of reality and the poet's interaction with it includes all aspects. According to Erich Auerbach, Baudelaire was the first poet "to give a sublime shape" to subjects of the classical aesthetic categories of "ridiculous", "low" and "grotesque" (Baudelaire 1987) whose definitions in this process cease to exist. Imagination can overcome the limits of definition and become a powerful means of perception and knowledge. Against the ease of Romantic art, Baudelaire counters with a mediated, conscious and voluntary art that makes the most intimate element of perception go through a continuous process of objectification which is visual, above all, but also olfactory, tactile and auditory (L'Enciclopedia UTET 2003, Vol.2, 732). The attention is driven again onto the poet as the only one capable of distinguishing the ties involved in the universe.

\section{Chen Jingrong Translating Baudelaire}

It is difficult to say why Chen chose to translate Baudelaire's poems. While she was translating them, China was undergoing major transformations that completely engulfed the Country. The $5^{\text {th }}$ Five Year Plan, which was going on, aimed at increasing industrial and agricultural production with the organization of communes. Private enterprises were undergoing the process of absorption into State-owned enterprises. The Constitution was approved. The Army was being modernized. On the international ground, new relations were being established with the Soviet Union. In addition, during the VIII Congress of the Chinese Communist Party (CCP) great developments of various production sectors had been confirmed, and the economical-financial crisis had begun following the decision to give priority to heavy industry. The leadership of the CCP was dealing with many conflicts that were to be expressed during the Hundred Flowers Campaign to be followed by the disastrous Great Leap Forward (Melis and Demarchi 1979). 
The general situation which provides the background in which Chen's translations of the French poems developed seems to be echoed in the poetic choices that she made.

The nine poems that Chen translated are: Le crépuscule du matin/Dawn (朦胧 的黎明, Menglong de liming), Le crépuscule du soir/Dusk (薄暮, Bo mu), Le cygnet/The Swan (天鹅, Tian'e), La mort de pauvres/The Death of the Poor (穷人 的死, Qiong ren de si), Sonnet d'automne/Autumn Sonnet (秋, Qiu), L'ennemi/The Enemy (仇敌, Choudi), Le flambeau vivant/The Living Torch (不灭的火炬, Bu mie de huoju), Spleen/Spleen-IV (忧郁病, Youyu bing), Harmonie du soir/The Harmony of Evening (黄昏的和谐, Huanghun de hexie). ${ }^{7}$ They are quite far from depicting a serene image of life. ${ }^{8}$ Indeed, the nine poems convey feelings of sadness, discomfort, ugliness, desperation without hope. In the poems she chose, hope is like the bat in Spleen, "S'en va battant les murs de son aile timide/Et se cognant la tête à des plafonds pourris"9 (Baudelaire 1928, 137). The cities are described as being inhabited by prostitutes, shivering beggars, poor people to whom only death brings some consolation. Above them, the cycle of nature follows unchangingly with indifference while life remains unpredictable. The unpredictability of life generates a sense of helplessness which not even love can mitigate. In fact, love makes use of tools such as crime ("crime"), horreur ("horror") and folie ("madness") (Sonnet d'automne) (Baudelaire 1928, 121).

Whereas nature is characterized by indifference, the action of time is even more devastating as it mange la vie ("eats life") (L'ennemi) (Baudelaire 1928, 28). In the same poem, the Enemy, which is written with a capital "E", raises further concern and a sense of uncertainty as there is no clue who "l'obscure Ennemi qui nous ronge le cœur" "10 (L'ennemi) (Baudelaire 1928, 28) it could be.

A close reading of Chen's translation of Baudelaire's poems shows her attention to details. One example, among others is her translation of Harmonie du

\footnotetext{
${ }^{7}$ The English translations of the French titles and verses of Baudelaire's poems are from: Charles Baudelaire The Flowers of Evil - A New Translation with Parallel French Text, translated with notes by James McGowan, Oxford World's Classics, Oxford University Press, 1993.

${ }^{8}$ My research on Chen Jingrong includes a section which focuses on the inter-relationship between Chinese intellectuals and the West. In this paper, which is a further step in my research, the part that "reads" Baudelaire, Chen Jingrong and Duo Duo together refers to my article "Poesia e intelligenza-Baudelaire sbarca in Cina" (Tamburello 2004, 2-3), where the comparative reading is more detailed.

9 "Batters the walls with her enfeebled wing/Striking her head against the rotting beams" (Baudelaire 1993, 149).

10 "That dark Enemy who gnaws our hearts" (Baudelaire 1993, 29).
} 
soir. Baudelaire's Alexandrine verses produce a very well organized rhythm that creates a kind of lullaby further stressed by the constant rhyming ABBA.

Due to the impossibility of re-creating this same rhyming in translation, it is one of the components that gets lost in translating between a Western language and Chinese. Chen ${ }^{11}$ proposed a diffused rhyming that allows for the reproduction of a quiet lullaby rhythm as in the original. It is useful to observe: yiyang一样 (“same") and huidang 回荡 (“to resound") at the end of verses 2 and 3 in which not only the last vowel is the same but also the tone of the words, the IV tone for both. This artifice is also found in other verses of the poem. Together with the repetition of an entire verse along the poem, it draws attention to the rhythmic element. This is very important because, while emphasizing the melancholy of the waltz which it describes, it brings into action the innovative technique of Baudelaire in creating a poetic experience that calls on all the senses. In this specific case, it is possible in fact to "see" (the flower), to "smell" (the censer) and to "hear" (the waltz, the violin) in the poem. ${ }^{12}$

Chen seems to be well aware of this and works on the rhythm as well as on the words. We find hua 花 (“flower”), xiang 香 (“perfume”), shengyin 声音 (“sound”), and so on.

Chen's work goes further on a deeper level. The way she translates s'est noyé ${ }^{13}$ (Baudelaire 1928, 89) ${ }^{14}$ is by using the verb chen 沉 ("heavy, to sink") that she uses recurrently, both as an attribute as well as a verb, conveying an idea of movement. Furthermore, in Huanghun de hexie she makes use of the word xiang 像 ("like/resembling"), to be found also in the translation she made of the other poems, which is fundamental in Baudelaire's poetics as a means of creating chains of associative references. ${ }^{15}$

We are perfectly aware of the problems that arise in the process of translating from one language into another. In some cases the problems are unavoidable, but,

\footnotetext{
${ }^{11}$ It is possible to refer to the nine poems by Baudelaire translated by Chen Jingrong by visiting: http://www.douban.com/group/topic/5524404/.

12 The version of Harmonie du soir I refer to are Baudelaire's (1928, 89); Chen Jingrong (1957) or in Tan Guilin (2004), and Baudelaire (1993, 96).

13 "Is drowning" (Baudelaire 1993, 97).

${ }^{14}$ I refer to the same sentence repeated in verses 12 and 15: "Le soleil s'est noyé dans son sang qui se fige/ The sun is drowning in its dark, congealing blood" (Baudelaire 1993, 97).

${ }^{15}$ Chen's translation work is extremely stimulating from the point of view of the theories of translation, but this topic should be developed in a different paper.
} 
it is notable that Chen brings to completion the process of trans-ducere ("translead"), of bringing into the Chinese culture a way of composing poetry that with Baudelaire, especially, results in a kind of combat between the reader and the text. This continuously grips the reader's attention by means of contents which are often unexpected, and by means of activating the senses. This is quite a step further on from the equilibrium produced in Chinese classical poetry, and yet another step further if considered against the background of a temporally nearer poetry that, based on the need to support the CCP policy, was required to praise the Party's steps forward as described in Chairman Mao's Yan'an talks of 1942 (Mao Tse-Tung 1942, 1-43).

\section{Duo Duo's Poetry à la Baudelaire: Zaihui}

When Duo Duo, one of the leading voices in the renewal of Chinese contemporary poetry, became acquainted with the Chinese translations of Baudelaire's poems by Chen Jingrong, he was a young man and China was in turmoil of the Cultural Revolution.

His first attempts at writing poetry were based on Song dynasty's ci ("poem") poems. He admits that he considered the act of writing $c i$ far too difficult for him, and therefore an unachievable goal. Reading Baudelaire through Chen's translations turned out to be an experience that would lead Duo Duo towards a different way of approaching and understanding poetry.

Duo Duo indicates Zaihui 再会 $^{16}$ as his first poem. He was born in 1951, and Zaihui was written in 1972. A parallel reading of this poem and the nine poems translated by Chen highlights many references to be found in terms of use of the words and also in terms of absorbed structural elements of the sentence, the use of xiang 像, to name only one. When extending the close reading to an analysis of the three authors together, the echoes throughout the different texts are quite impressive. ${ }^{17}$ Here, it could be interesting to put forward an analysis that I have made $^{18}$ which shows, in my opinion, how in Zaihui Duo Duo was somehow

\footnotetext{
${ }^{16}$ My Italian translation of Zaihui can be found in Duo Duo, Canto, trans. Giusi Tamburello (1998, 9).

${ }^{17}$ For a detailed analysis of these aspects of Duo Duo's poem see the reference in foonote 8 .

${ }^{18}$ See the reference in footnote 8 .
} 
practicing the future direction that he was to give to Chinese poetry by writing a poem, if I may say so, à la Baudelaire.

In order to illustrate what I have in mind, I shall take into consideration Zaihui in relation to Le crépuscule du soir (Baudelaire 1928, 177-8) because it seems to me that they have a parallel development. The two poems read as follows:

\section{Le crépuscule du soir}

Voici le soir charmant, ami du criminel;

II vient comme un complice, à pas de loup; le ciel

Se ferme lentement comme une grande alcôve,

Et l'homme impatient se change en bête fauve.

O soir, aimable soir, désiré par celui

Dont les bras, sans mentir, peuvent dire: Aujourd'hui

Nous avons travaillé! — C'est le soir qui soulage

Les esprits que dévore une douleur sauvage,

Le savant obstiné dont le front s'alourdit,

Et l'ouvrier courbé qui regagne son lit.

Cependant des démons malsains dans l'atmosphère

S'éveillent lourdement, comme des gens d'affaire,

Et cognent en volant les volets et l'auvent.

À travers les lueurs que tourmente le vent

La Prostitution s'allume dans les rues;

Comme une fourmilière elle ouvre ses issues;

Partout elle se fraye un occulte chemin,

Ainsi que l'ennemi qui tente un coup de main;

Elle remue au sein de la cité de fange

Comme un ver qui dérobe à l'Homme ce qu'il mange.

On entend çà et là les cuisines siffler,

Les théâtres glapir, les orchestres ronfler;

Les tables d'hôte, dont le jeu fait les délices, 
S'emplissent de catins et d'escrocs, leurs complices,

Et les voleurs, qui n'ont ni trêve ni merci,

Vont bientôt commencer leur travail, eux aussi,

Et forcer doucement les portes et les caisses

Pour vivre quelques jours et vêtir leurs maîtresses.

Recueille-toi, mon âme, en ce grave moment,

Et ferme ton oreille à ce rugissement.

C'est l'heure où les douleurs des malades s'aigrissent!

La sombre Nuit les prend à la gorge; ils finissent

Leur destinée et vont vers le gouffre commun;

L'hôpital se remplit de leurs soupirs.-Plus d'un

Ne viendra plus chercher la soupe parfumée,

Au coin du feu, le soir, auprès d'une âme aimée.

Encore la plupart n'ont-ils jamais connu

La douceur du foyer et n'ont jamais vécu! (Baudelaire 1928, 177-8)

\section{Dusk}

Sweet evening comes, friend of the criminal,

Like an accomplice with a light footfall;

The sky shuts on itself as though a tomb,

And man turns beast within his restless room.

O evening, night, so wished for by the one

Whose honest, weary arms can say: We've done

Our work today! - The night will bring relief

To spirits who consume themselves with grief,

The scholar who is bowed with heavy head,

The broken worker falling into bed. 
Meanwhile, corrupting demons of the air

Slowly wake up like men of great affairs,

And, flying, bump our shatters and our eaves.

Against the glimmerings teased by the breeze

Old Prostitution blazes in the streets;

She opens out her nest-of-ants retreat;

Everywhere she clears the secret routes,

A stealthy force preparing for a coup;

She moves within this city made of mud,

A worm steals from man his daily food.

One bears the hissing kitchens close at hand,

The playhouse screech, the blaring of a band.

The tables at the inns where gamesmen sport

Are full of swindlers, sluts, and all their sort.

Robbers who show no pity to their prey

Get ready for their nightly work-a-day

Of cracking safes and deftly forcing doors,

To live a few days more and dress their whores.

Collect yourself, my soul, in this grave time,

And shut out all this clamour from the slime.

This the time of sick men's sharpest pain!

Black night will grab their throats; they cry in vain,

And finish out their fate in common grave;

The hospital is filled with grasps. They have

No further need to think of evenings' spent

At fireside - the fragrant soup, the friend.

But most of them have never known the call

Of friendly hearth, have never lived at all!

(Baudelaire 1993, 193 and 195) 


\section{再会 (Zaihui)}

前面是苍茫的原野

乡间晚䘠的钟声

一下一下，落到荒凉的心上

沉缓而且庄严

和着徐徐降下的黄昏

迷恫, 难过的感情, 在闪烁

在苏醒它们星星点点的微光

\section{阿门}

钟, 仍在空阔辽远地送响

徒然反省没有作错的一切

泥土在脚下永远是纯朴的见证

晚风吹拂起长长的披肩发

那些位立的人们, 相对无语

只一齐扭过身来, 向着他, 深

[深地鞠了一躬 (Duo Duo 1998, 8)

\section{Goodbye}

Ahead is an expanse of wilderness

in the countryside, the sound of the evening prayer bell stroke after stroke, it falls on the desolate heart

heavy and solemn

following the twilight which slowly fades

perplexing, painful feelings, a gleam of uncertain light

revive faint fragmented rays

amen

the bell sends its sound out into the open space, away it goes

in vain questioning what was not wrong

the earth beneath the feet is always an honest witness

the evening breeze blows about the long hair on their shoulders

those people long standing, facing each other without words

all turn at once, towards him, bowing deeply 
In both poems, the first part defines the space-time connotation. In French, we find the ciel, which transmits a sense of wideness, in the soir charmante. In Chinese, the image is an “immense”/cangmang 苍茫 “countryside”/yuanye 原野 during the “evening prayer"/wandao 晚䘠.

At this point, a moment of pause follows during which a meditation is expressed. In French: "C'est le soir qui soulage/Les esprits que dévore une douleur sauvage//The night will bring relief/To spirits who consume themselves with grief", then again: “Cependant des démons malsains dans l'atmosphère/ S'évellent lourdement//Meanwhile, corrupting demons of the air/Slowly wake up", and finally: "Elle remue au sein de la cité de fange/Comme un ver qui dérobe à l'Homme ce qu'il mange//She moves within this city made of mud,/A worm steals from man his daily food". In Chinese, verses 5-7:

和着徐徐降下的黄昏

迷惆, 难过的感情, 在闪炼

在苏醒它们星星点点的微光

(following the twilight which slowly declines

perplexity, painful feelings, a gleam of uncertain light

revive their faint fragmented rays).

In both poems, the second part introduces the auditory element. In French: "On entend çà et là les cuisines siffler/Les théâtres glapir, les orchestres ronfler//One bears the hissing kitchens close at hand,/The playhouse screech, the blaring of a band." In Chinese, verse 9:

\section{钟, 仍在空阔辽远地送响}

(the bell transmits sound into the open space, away).

Then, one more moment of meditation follows. In French: "Recueille-toi, mon âme, en ce grave moment,/Et ferme ton oreille à ce rugissement//Collect yourself, my soul, in this grave time,/And shut out all this clamour from the slime." In Chinese, verses 10-11:

徒然反省没有作错的一切

泥土在脚下永远是纯朴的见证 
(vain questioning of what was not wrong

the earth beneath your feet is always an honest witness).

The last meditation concludes the poem. In French: "Encore la plupart n'ont-ils jamais connu/La douceur du foyer et n'ont jamais vécu!//But most of them have never known the call/Of friendly hearth, have never lived at all!" In Chinese, verses 13-14:

那些位立的人们, 相对无语

只一齐扭过身来，向着他，深 深地鞠了一躬

(those people long standing, facing each other without words

at once all turn toward him, making a deep bow).

Through this parallel reading, it would seem that Duo Duo is willing to test himself on a Baudelaire-like style. He arranges the poem along the same kind of divisions as the French poem, but, clearly, his motives are different. It seems as if he is trying to adapt a foreign "dress" to a Chinese "content". But it is not entirely so because the text has been "contaminated" by words of a foreign reality: the evening prayer, the bell, the word "amen" (阿门 in the Chinese poem), the long hair on the shoulder.

If we then proceed to a further comparison, this time between Zaihui and Bomu 薄暮 (Dusk), with the translation of Le crépuscule du soir made by Chen Jingrong, compared to Duo Duo's poetry, we can see that the echo effect is more evident.

Here is Chen's version:

\section{薄暮 (Dusk)}

迷人的黄昏到了，它是罪恶的帮凶;

像个同谋犯似的蹑足走来; 天空

犹如巨大的卧室慢慢合上,

人，心烦意乱，野兽般疯狂。

呵, 黄昏, 可爱的黄昏, 那些人期待你,

因为他们敢于伸出手臂, 诚实的 
说: “我们又劳动了一天! ”黄昏抚慰着

那些被剧痛吞噬的心灵:

那孜孜不倦的沉思的学者,

那重新找到卧床的腰瘦背痛的工人。

这时, 那些狠毒的恶魔, 在四周

昏昏沉沉的醒来, 像忙碌的商人,

飞跑去敲吒人家的屋檐和门窗。

透过被风摇动的灯光,

娼妓们又活跃在街上，

像个蚂蚁窝, 她们把所有的门户打开;

到处给自己䢃一条隐蔽的道路,

就像是敌人偷偷的袭来,

他们在污秽的城中蠕动,

像尸虫在人体上偷取食物把自己供奉。

这里那里, 厨房在嘶嘶的响,

剧场在喧器, 乐队在呼噜,

奢性方酣的客厅里

挤满了荡妇, 还有骗子一一她们的同谋,

那些小偷, 既不肯罢手也没有慈悲,

他们也就要开始他们的勾当,

就要去轻轻扭开门窗和箱㴟,

为了吃喝几天, 为了打扮他们的情妇。

在这庄严的时刻, 我的灵魂, 你沉思吧,

掩住耳朵, 别听他们的喧哗。

这种时候, 病人会更加痛苦难当,

阴暗的黑夜捏紧了他们的喉咙;

他们将结束自己的命运, 走向那共同的深渊;

病院里充满了他们的呻吟一一不止一个

将不复归来寻找那美味的美汤,

在黄昏, 在炉边, 在亲人身旁。

他们中间还有很多人,从来没有尝过

家的甜蜜,从来就不曾生活过！(Douban)

Since every author has his/her original way of composing, the elements that will follow can only be a suggestion of influence, but they seem to me remarkable anyway.

The word huanghun 黄昏 (“dusk”) appears both in Chen's translation and in Duo Duo's poem. 
The personification of an object, the huanghun, addressed with a ta 它 ("it") of the object, but followed by shi zui'e de bangxiong 是罪恶的帮凶 ${ }^{19}$, in verse 1 , is to be found also in verses 6 and 7 of Zaihui: "miwang, nanguo de ganqing, zai shanshuo/zai suxing tamen xingxing diandian de weiguang/迷惘, 难过的感情, 在闪炼/在苏醒它们星星点点的微光.//perplexing, painful feelings, a gleam of uncertain light/revive faint fragmented rays".

In Chen's verse 5, we find: naxie ren 那些人 (“those people”). In verse 13 of Zaihui, we read: naxie zhuli de renmen 那些位立的人们 (“those people long standing").

The description of the movement caught in its actual happening as in the construction: shen chu shoubei 伸出手臂 (literally: “stretch their arms") in verse 6 of Chen's translation, appears also in verse 14 of Zaihui: "yiqi niu guo shen lai 齐扭过身来//all turn at once, towards him, bowing deeply".

In verse 8 of Chen's version, jutong 剧痛 (“intense pain”), as well as chensi 沉 思(“ponder, meditate”) in the following verse, bring in an atmosphere that is recognizable in miwang, nanguo de ganqing 迷惘, 难过的感情 (“perplexing, painful feelings, a gleam of uncertain light") of verse 6 of Zaihui, without forgetting the specific weight of the word chen 沉 which has already been noted before in this paper.

Also the doubling of the adjective or the adverb, for instance, in verse 12 of Chen's version, hunhun chenchen 昏昏沉沉 (“murky, dazed”) is used very often by Duo Duo as he does it in verse 5 with $x и х и$ 徐徐 (“slowly, gently”) and in verse 7 with xingxing diandian 星星点点 (“tiny spots, bits and pieces”) in Zaihui.

These are just a few observations concerning the possible influences of Baudelaire's poetry on Duo Duo's poetic style through the intermediation of Chen Jingrong's translations from the French language. Whether the above observations are grounded or not, I do not know. This opinion, according to Spitzer, can always be confused by a different starting point in the analysis. Nevertheless, in my perception, all three poems convey the same kind of mood, though each author makes his/her own stylistic choices.

\footnotetext{
${ }^{19}$ Literally: "it is the accomplice of evil". (The translation is mine)
} 
In the specific case of Duo Duo, no matter what his source of inspiration is to write Zaihui, the poem shows a shifting towards a "foreign" method of composition.

\section{Referring to the West}

If compared to some years ago, the amount of information that is available nowadays about China has increased to an astonishing degree. The idea of China as a country characterized by a "closed" culture has been broken into pieces. But even when recalling the idea of a "closed" culture, we should perhaps ask ourselves whether or not that idea was created by the West. If we think in fact, of the $20^{\text {th }}$ century, for instance, China was hardly never "far" from the West. It was difficult, if not impossible, for the West to "enter" China at will, but China was "absorbing" and "digesting" many aspects of the Western cultural essence. Marxism is just one of the possible examples.

In periods of deep historical transformations, Chinese intellectuals have referred to Western cultures out of a genuine curiosity, but have also been pushed in that direction by a desire for knowledge, a knowledge that could supply further means for change. In the beginning of the last century, for example, there were many ideas circulating around the May $4^{\text {th }}$ Movement of 1919 that derived from the West, and there were also many intellectuals who in those years were travelling back and forth from Europe, America, and also Japan, a country quite "exposed" to the West.

In fact, if we look at it more attentively, we could also say that during the whole of the $20^{\text {th }}$ century China was interacting with the West, so it was far from being a "closed" culture. It might be better to say that, seen from the Western point of view, China was "closed" to the West, but from the Chinese point of view, China was studying, exploring, and making selections of what in the West was useful to her. Behind the apparent curtain of a "closed" culture, China was keeping a watchful and eager eye on the West.

In more recent times, during the Cultural Revolution (lasting with its aftermath from 1966 to 1976), and also afterwards, during the beginning of the post-Mao era (Chairman Mao passed away in September 1976), there was a new wave of interest towards the West. Although it was forbidden, foreign books were read during the Cultural Revolution, but not openly. Literature that was circulating was 
found in underground circuits. The absorption of the West continued also during the Eighties when the Chinese narrative was represented by a very remarkable amount of works that found stimuli in postmodernism, in the magic realism from South-America or, for instance, in Freudian theories.

There is nevertheless, among others, a very peculiar characteristic that differentiates the interest towards the West manifested during the Cultural Revolution and during the $80 \mathrm{~s}$ from that of the beginning of the $20^{\text {th }}$ century. At that time, intellectuals would go abroad mostly to study, and they would spend enough time in the foreign country to learn the local language which, once they were back in China, would be used in many cases for translation. Their knowledge of foreign languages allowed them a first-hand approach to sources. The young intellectuals who, during the Cultural Revolution or after, did not attend university and went to the countryside, in most cases did not know a foreign language. They were approaching foreign books in what was already a product of a first cultural "digesting" process carried out by the translator.

This was also the way in which Duo Duo approached Baudelaire's poetry. He read, in fact, Chen Jingrong's translation and discovered a way to write poetry which had hitherto been unknown to him.

At that time, towards the end of the $60 \mathrm{~s}$ and the beginning of the $70 \mathrm{~s}$, still immersed in the experience of the Cultural Revolution which had meant, for many young people, a radical break with anything that was recognizable as fundamental in Chinese culture - family, school, friends - many young people were searching for a means of somehow re-appropriating their culture. For some of them this was offered through poetry, which is and was the very essence of the Chinese culture.

According to Henry Y.H. Zhao (1994, 155-68), the long lasting survival of the Chinese culture is linked not with its hyper-stability, but rather with its capacity for re-orientating itself. In periods of chaos, the activity bound to the Continuity of Letters has the task not only of guaranteeing survival, but also of creating new opportunities for re-orientation. Zhao explains that in periods of re-orientation Chinese culture is confronted with what already exists, which is to say with pretextuality, therefore literature of these periods can only be different from that of periods of stability. In periods of re-orientation, new codes of meaning are built on a criticism of pretextuality, therefore, literature becomes strongly counter-cultural, and because of this it offers the possibility of re-orientation. According to Zhao, counter-culture should not be seen as successful or unsuccessful, but rather as a 
necessary element that moves towards the creation of a possible path to follow when re-orientation is completed. From this it follows that the subversive power of counter-culture is felt only in a metaphorical sense.

Some of the young people sent to the countryside during the Cultural Revolution, having experienced the conflict between political discourse and personal suffering generated from its actuation, discovered themselves as poets and searched in poetry for a way to give voice to feelings and emotions that were new to them because they were produced by an unexpected turn of the political discourse. The slogans shouted during the Cultural Revolution could not express the sense of amazement that the very event produced in young people, who began working with poetic expressions at that time when they were just teenagers.

In his analysis of language and political discourse in contemporary China, Maurizio Marinelli writes:

This socio-psychological mechanism of imposition combined with emotional internalization of a prescribed unilateral form of expression demonstrated all its effectiveness during the Cultural Revolution (1966-1976). During that period the alignment with the only authorized expressive code reached its climax (and also its point of no return) as is evident at the start in the case of the "docile bodies" of Chinese intellectuals. Language in China has been identified and widely used for decades as the most suitable tool to confine the possibility of expressing (and, although to a different extent, even experiencing) socially accepted perceptions within the limits prescribed by the "correct interpretation" of reality, a regulation which is strictly considered the prerogative of the Chinese Communist Party (CCP) leaders. At the individual level, the internalization of the lexical items, the set of categories, and the rules of combination codified by the formalized language have been imposed and considered the standard to prove and test the correctness of the individual's political thought. From the point of view of the receiver, language functions both as the medium to externalize the consciousness of society, and to express the individual search for subjectivity. From this perspective, the master narrative of Chinese political language in the post-Mao era is the story of a progressive and unstoppable devolution, that I would term dematerialization of the collective psycho-emotional universe. (Marinelli 2003-2004, 147-8)

What Marinelli terms "dematerialization" is, in fact, the process that can be observed in the poetry written by the young poets towards the end of the Sixties, where their inspiration abandons the collective dimension and shifts to a subjective one. The enthusiastic atmosphere to be found in the poems of the 50s leaves room for an uncertainty which is newly felt. 
This feeling that had completely disappeared from the poems, that for instance during the 50s had followed the affirmation of the CCP on the national political scene, reappears powerfully. The young poets searched for ways to express it. Each of them followed his/her inspiration and, later on, style.

\section{Drawing on a Western Basis: Translation as Renovation Factor}

Duo Duo, at first, experiments with the composition of $c i$ poems in the Song style only to give up the attempt very soon. He finds their level too high to be reached. Nevertheless, it could be assumed that he is acquainted with the musicality given to the $c i$ by the well defined rules of composition concerning the number of characters and the sequence of tones. Indeed, music is a very important factor in Duo Duo's poems. He has stated that, among the various kinds of poetry of the Chinese tradition, his poetry can be included in the category of poetry that has the character of song since for him the most beautiful sound to hear is the sound of a human voice singing, and above all the voice of a tenor (Duo Duo 1998, 148). And perhaps, his acquaintance with $c i$ poems has also produced that kind of internal equilibrium of composition that is to be found in his poems and that is in direct line with his Chinese cultural tradition.

But what is it then that provokes Duo Duo's enthusiasm towards the translations made by Chen Jingrong of the poems of Baudelaire?

In a close reading of Duo Duo's poems of the 70s, his first poems and those of the following years, the reader is confronted with an overwhelming succession of images (Duo Duo 1998, 138-9). Somehow, each verse creates an image:

歌声, 省略了革命的血腥

(the sound of chants ignores the smell of blood of the Revolution) ${ }^{20}$

教育和儿童被脏手扼住喉咙

(teaching and children were grabbed by the throat by dirty hands) ${ }^{21}$

\footnotetext{
${ }^{20}$ From Dang renmin cong ganlao shang zhanqi 当人民从干酪上站起 (When People Rise from Cheese), Duo Duo 1998, 10, v. 1.

${ }^{21}$ From Zhong wei shui ming 钟为谁鸣 (For Whom the Bell Tolls), Duo Duo 1998, 12, v. 3.
} 
叶落到要去的路上

(leaves fall on the way to go $)^{22}$

The list stretches on as each verse succeeds in creating an image. Therefore, while reading, it becomes possible to actually "see" Duo Duo's poem. Furthermore, as explained before in Zaihui, Duo Duo's poems also activate other senses.

It seems to me as if Duo Duo through Chen Jingrong's translations captures some essential components of Baudelaire's poetics, which is to say the relation of the poet with the image, his ability to stimulate the senses, and his different kind of appreciation of beauty.

This is what is remarkable in Duo Duo's poetry as well. As a first attempt, we could say that Zaihui follows Baudelaire's style very closely, but very soon Duo Duo will be mature in his own personal style. Searching for a means of expressing a new consciousness of the relationship between the individual and life, Duo Duo will make powerful use of the "discovery" he makes of Baudelaire's poems to enrich the Chinese poetic language of images that grab the readers' attention.

He obtains this result by means of describing disturbing images of which the following is just one possible example:

牲口被蒙上了野蛮的眼罩

屁股上挂着发黑的尸体像肿大的鼓

直到篱笆后面的牺牲也渐渐模糊

(the beasts of burden's eyes have been cruelly covered

swollen like drums, blackening corpses dangle from their buttocks

until the sacrifice behind the fence gradually fades $)^{23}$

By doing this, he creates a very strong interference with the elegance and sense of harmony of the contents intrinsic to Chinese poetry.

In addition, Duo Duo pushes this effect to the extreme by creating what I have defined as "logical inversions" (Duo Duo 1998, 140). He creates images that are unfamiliar to the reader because they break with his/her "logical" expectations. It is possible to observe a so-called "logical inversion" in the following example:

${ }^{22}$ From Mizhou 蜜周 (Week of Honey), Duo Duo 1998, 14, v. 1 .

${ }^{23}$ From Duo Duo 1998, 10, v. 5-7. 
当你又从末日向春天走来

复活的路上横着你用旧的尸体

(when from Doomsday you walk back to the Spring

on the road to resurrection lies your worn corpse $)^{24}$

in which a very strong contrast is created between the idea of Doomsday and the action of walking back from it, and, what is more, towards Spring. To accentuate the "logical inversion", the corpse lies on the road to Resurrection.

In The Poet's Death, another example is found:

灵魂的大门, 在庄严地关闭

送我加入迎娶生命的殡列

(the door of the soul, solemn closes

it accompanies me to the ranks of those who follow the funeral

to which it marries my life $)^{25}$

After the first moment of disorientation, the reader is directed towards the search for a possible meaning behind the "logical inversion". There are many examples of such a procedure in Duo Duo's poems and each time the inversion opens up a different realm of understanding. The reference to Doomsday, for instance, directs the reader towards another world. The action depicts the movement of walking away from that world, back towards the world of reality and towards something like Spring which might also suggest the idea of youth.

Duo Duo's "logical inversions" also suggest another element of interest which focuses mainly on a peculiar approach to the aspect of time. The way Duo Duo deals with time, its movement from a world of life to a world of death and back, seems to suggest more than one temporal dimension. This might be influenced by the concept of time in Chinese philosophy, or by discoveries in the contemporary world of physics, or even by the idea of correspondances as developed by Baudelaire. In any case, each of these possibilities suggests a problematic

\footnotetext{
${ }^{24}$ From Zhi qingdi 致情敌 (To Love Rival), (Duo Duo 1998, 22, v. 3-4)

${ }^{25}$ From Shiren zhi si 诗人之死 (The Death of the Poet), (Duo Duo 1998, 40, v. 14-15.)
} 
approach to time as if to stress the problematic essence of the reality of that time, of which many young people in China, including Duo Duo, had direct experience with.

As in the best Chinese tradition, Duo Duo's early poems offer the chance to play the game of Chinese boxes, which like Russian matryoshka dolls, keep opening to another box of meaning, suggestion or thought. By getting back to the image, the macroscopic element of the influence of Baudelaire's poems on Duo Duo's, it is possible to observe one more element of interest.

In his La Folie Baudelaire, Roberto Calasso writes:

When photography appeared - and the world was preparing to reproduce itself indefinite times more than usual—ready to welcome it there was already a concupiscentia oculorum in which some people would recognize themselves with the immediate complicity of the perverse. "This sin is our sin [...] Never an eye was more eager than ours" Gautier explained. And Baudelaire's voice mingled with his: "very young, filled with painted or carved images, my eyes never got satiated, and I think that the world could end, impavidum ferient, before I become iconoclastic." Instead, a small tribe of image worshippers was formed.

They explored the intricacies of big cities, immersing themselves in the "delights of chaos and immensity full of idols".

The eagerness of the eyes, nourished by countless objects of art sifted and scrutinized, was a powerful stimulus for the prose of Baudelaire. He trained his pen to "fight against plastic representations." And it was Hypnerotomachia, a "fight for love in a dream," more than a war. Baudelaire was not passionate about inventing from scratch. He always needed to elaborate on pre-existing material, some ghost glimpsed in a gallery or in a book or on the street, as if writing was primarily a work of transposition of forms from one register to another. This method is how some of his perfect sentences were created, which are to be contemplated for a long time, and which let us quickly forget that they could be the description of a watercolour [...]. Very little can be captured of Baudelaire's by those who do not participate to some extent in his unique devotion, which is to the images he created. If a confession is to be understood literally, and with all of its consequences, it is stated in one sentence, Mon cour mis à nu: "Glorify the worship of images (my great, my only, my primitive passion)." (Calasso 2008, 22-3)

The long quotation very densely focuses on the importance of images for Baudelaire, and allows me an attempt to provide another reason why Duo Duo was stimulated by Baudelaire's poetry to write poems in the same manner as he did. 
Somehow, the power of Baudelaire's images could work as an enhancement factor of the intrinsic nature of images of Chinese characters. The visual nature of Chinese characters is what gets immediately lost in translation. The visual nature of Chinese characters is that something which makes a Chinese person, when looking for instance at a made-up name created for a foreign person, exclaim: "Oh, what beautiful characters you have chosen!" As a foreigner, the person appreciates the compliment, but does not really understand it wholly. The nature of Chinese characters is visual since they keep their very root which was that of depicting reality, though nowadays in a simplified form which takes away part of the meaning's connections. Baudelaire's verses that so intensely draw on images might have offered Duo Duo the possibility of getting back to the essence of the Chinese characters' ability to depict the actual reality he was immersed in.

The translation made by Chen Jingrong, in its turn, presented Duo Duo with a ready-made product in which the immediate problematic aspects of the language had already been resolved and converted into a fluent Chinese language that could act as the bridge between the French poet and the young Duo Duo, who knew nothing of the French language.

The linguistic choices had already been made by Chen, and Duo Duo could absorb them at ease and pass them on to the next step of elaboration. One example, among others, concerns the word chen 沉 as alluded to earlier in this paper. To get back to Zaihui (Duo Duo 1998, 8), in verses 3 and 4 we read: “[...] 落到荒凉的欣 赏/沉缓 $[\ldots] /[\ldots]$ falls on the bare heart/sinks [...]", where "falls" is represented by luo 落, and "sinks" by chen 沉. Both these verbs convey an idea of weight and gravity that also comes back in the value of chen 沉 as the attribute "heavy" that Duo Duo combines with huan 缓 that means "slow". In Les crépuscule du matin (Dawn) (Baudelaire 1928, 196), in verse 7 we read that the soul is to be found: "sous le poids du corpe revêche et lourd//in the burden of the body's sway" (Baudelaire 1993, 211). To translate "lourd/heavy", Chen (1957, 134) chooses chenzhong 沉重 ("heavy”) where the component chen 沉 ("heavy, to sink") is to be found again. 


\section{Conclusion}

From the first publication of Les fleurs du mal in Paris in 1857 to the publication of Chen Jingrong's translation in 1957, a hundred years had passed. Some twenty years later, Duo Duo's first poem Zaihui came into existence, and he turned out to be among those who changed Chinese contemporary poetry by renovating it. It is not possible to understand Duo Duo's poetry and sources of inspiration without considering the contribution made by Chen Jingrong and her translations of Baudelaire directly from the French language into Chinese.

Much research still remains to be done in order to fully understand the interaction between the texts of these three intellectuals over a wide span of time, and their implications.

Whenever China needs the West, she gathers up a handful. The long cultural tradition of China allows her people to elaborate on these external contributions in an original way. Nevertheless, the work done by people like Chen Jingrong needs to be considered as a chapter apart. She is one of those who with their cultural engagement and passionate translation work paved the way for major transformation in the culture of China.

\section{References:}

Baudelaire, Charles. 1928. Le fleurs du mal. Paris: Payot.

—. 1973. Le fleurs du mal. Edited by Y. Florenne. Preface by M.J. Durry. Paris: Le livre de poche.

—. 1987. I fiori del male. Translated by Giovanni Raboni. Torino: Einaudi.

—. 1993. The Flowers of Evil. Translated by James McGowan. Oxford: Oxford University Press.

Calasso, Roberto. 2008. La Folie Baudelaire. Milan: Adelphi.

Chen, Jingrong 陈敬容. 1957. “Bodelai'er. E zhi hua”波德莱尔。恶之花 (“Baudelaire. Les fleurs du mal.”) Yiwen 译文: 132-43.

“Douban." Accessed July 27 2012. http://www.douban.com/group/topic/5524404/.

Duo, Duo. 1998. Canto (Singing). Translated by Giusi Tamburello. Milan: Libri Scheiwiller.

Edmond, Jacob. 2010. "The Flâneur in Exile.” Comparative Literature 62 (4): 376-98. 
L'enciclopedia UTET. 2003. Vol. 2. Torino: Istituto Geografico De Agostini. Novara: Gruppo Editoriale L'Espresso.

Mao, Tse-Tung. 1942. "Talks at the Yenan Forum on Literature and Art.” In Mao TseTung on Literature and Art, 1-43. Peking: Foreign Language Press.

Marinelli, Maurizio. 2003-2004. "The Desire for Power and the Annihilation of Emotions in Chinese Political Language.” In Ming Qing yanjiu, edited by Paolo Santangelo, 143-59. Naples: Dipartimento di Studi Asiatici. Università degli Studi di Napoli "L'Orientale".

Melis, Giorgio, and Demarchi, Franco, eds. 1979. La Cina contemporanea (Contemporary China). Roma: Edizioni Paoline.

Rella, Franco, ed. 1990. Bellezza e verità (Beauty and Truth). Milan: Feltrinelli.

Spitzer, Leo. 1966. Critica stilistica e semantica storica (Stylistic Criticism and Historical Semantics). Bari: Editori Laterza.

Tamburello, Giusi. 2004. "Poesia e intelligenza - Baudelaire sbarca in Cina." ("Poetry and Intelligence - Baudelaire Lands in China"). Critica sociale, Cuore e Critica (Social Criticism, Heart and Criticism): 2-3.

—. 2009. "L'acqua nei versi di Chen Jingrong" ("Water as Described in Chen Jingrong's Poems"). In L'acqua non è mai la stessa. Le acque nella tradizione culturale dell'Asia. Atti del Seminario (Lecce, 18 aprile 2007), edited by Carolina Negri and Giusi Tamburello, 87-102. Firenze: Leo S. Olschki Editore.

Tan, Guilin 谭桂林. 2004. “Bodelai’er yu Zhongguo xiandai wenxue” 波德莱尔与中国 现代文学 (“Baudelaire and Chinese Modern Literature”). In Zhongguo xiandai wenxue shi 中国现代文学史 (History of Modern Chinese Literature) 4: 1-2. Accessed February 19, 2012. http://resource.jingpinke.com/details?uuid=ff808081-295875670129-58763ca7-55ab\&objectId=oid:ff808081-29587567-0129-58763ca7-55ac

Zhao, Henry Y.H. 1994. "Sensing the Shift. New Wave Literature and Chinese Culture." In Under-sky Underground Chinese Writings, edited by Henry Y.H. Zhao and John Cayley, 155-68. London: Wellsleep. 